\title{
CLIMATE CHANGE: THE IPCC SCIENTIFIC ASSESSMENT
}

The World Meteorological Organization and the United Nations Environmental programme have jointly sponsored an Intergovernmental Panel on Climate Change IPCC). Several hundred scientists from 25 countries have participated in preparing and reviewing the scientific data. The results were published by Cambridge University Press under the editorship of I.T. Houghton, G.J. Jenkins and J.J. Ephraums of The British Meteorological Office during 1990 under the above title.

The local representative of Cambridge University Press, Mr C. Voigt (Tel. 837-2051, fax 837-2271) has arranged for permission to publish excerpts from the book in the next two issues of the Journal. The excerpt are taken mainly from the Policymaker's Summary of the book. The summary is supported by chapters on various detailed aspects of climate change, each written by express in their respective fields. The results is "the most authoritative and strongly supported statement on climate change that has ever been made by the international scientific community."

\section{EXECUTIVE SUMMARY - (Continued)}

\section{How much do we expect climate to change?}

It is relatively easy to determine the direct effect of the increased radiative forcing due to increases in greenhouse gases. However, as climate begins to warm, various processes act to amplify (through positive feedbacks) or reduce (through negative feedbacks) the warming. The main feedbacks which have been identified are due to changes in water vapour, sea-ice, clouds and the oceans.

The best tools we have which take the above feedbacks into account (but do not include greenhouse gas feedbacks) are three-dimensional mathematical models of the climate system (atmosphere-ocean-ice-land), known as General Circulation Models (GCMs). They synthesise our knowledge of the physical and dynamical processes in the overall system and allow for the complex interactions between the various components. However, in their current state of development, the descriptions of many of the processes involved are comparatively crude. Because of this, considerable uncertainty is attached to these predictions of climate change, which is reflected in the range of values given; further details are given in a later section.

The estimates of climate change presented here are based on:

i) the "best-estimate" of equilibrium climate sensitivity (i.e. the equilibrium temperature change due to a doubling of carbon dioxide in the atmosphere) obtained from model simulations, feedback analyses and observational considerations (see later box: "What tools do we use?")

ii) a "box-diffusion-upwelling" ocean-atmosphere climate model which translates the greenhouse forcing into the evolution of the temperature response for the prescribed climate sensitivity. (This simple model has been calibrated against more complex atmosphereocean coupled GCMs for situations where the more complex models have been run).

\section{How quickly will global climate change?}

\section{a. If emissions follow a Business-as-Usual pattern}

Under the IPCC Business-as-Usual (Scenario A) emissions of greenhouse gases, the average rate of increase of global mean temperature during the next century is estimated to be about $0.3^{\circ} \mathrm{C}$ per decade (with an uncertainty range of $0.2^{\circ} \mathrm{C}$ to $0.5^{\circ} \mathrm{C}$ ). This will result in a likely increase in global mean temperature of about $1^{\circ} \mathrm{C}$ above the present value (about $2^{\circ} \mathrm{C}$ above that in the preindustrial period) by 2025 and $3^{\circ} \mathrm{C}$ above today's (about $4^{\circ} \mathrm{C}$ above pre-industrial) before the end of the next century.

The projected temperature rise out to the year 2100, with high, low and best-estimate climate responses, is shown in Figure 3. Because of other factors which influence climate, we would not expect the rise to be a steady one.

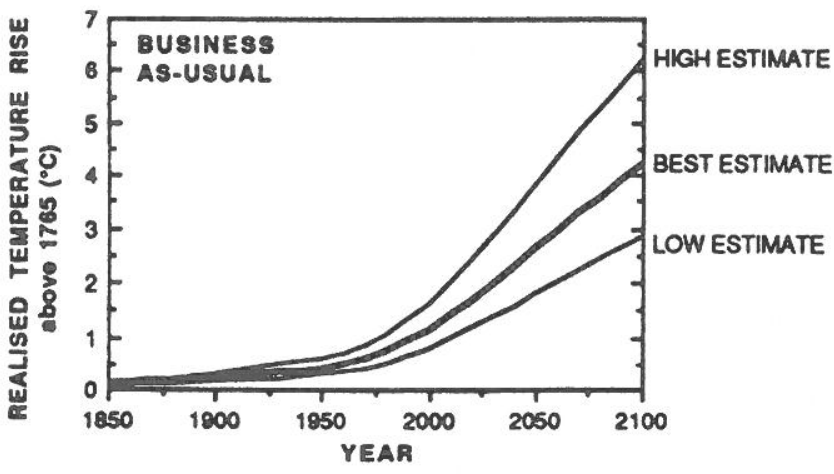

Figure 3 - Simulation of the increase in global mean temperature from 1850-1990 due to observed increases in greenhouse gases, and predictions of the rise between 1990 and 2100 resulting from the Business-as-Usual emissions.

The temperature rises shown above are realised temperatures; at any time we would also be committed to a further temperature rise toward the equilibrium temperature. For the $\mathrm{BaU}$ "best-estimate" case in the year 2030 , for example, a further $0.9^{\circ} \mathrm{C}$ rise would be expected, about $0.2^{\circ} \mathrm{C}$ of which would be realised by 2050 (in addition to changes due to further greenhouse gas increases); the rest would become apparent in decades or centuries.

Even if we were able to stabilise emissions of each of the greenhouse gases at present day levels from now on, the temperature is predicted to rise by about $0.2^{\circ} \mathrm{C}$ per decade for the first few decades.

The global warming will also lead to increased global average precipitation and evaporation of a few percent by 2030. Areas of sea-ice and snow are expected to diminish.

\section{b. If emissions are subject to controls}

Under the other IPCC emission scenarios which assume progressively increasing levels of controls, average rates of increase in global mean temperature over the next century 
are estimated to be about $0.2^{\circ} \mathrm{C}$ per decade (Scenario $\mathrm{B}$ ), just above $0.1^{\circ} \mathrm{C}$ per decade (Scenario $\mathrm{C}$ ) and about $0.1^{\circ} \mathrm{C}$ per decade (Scenario D). The results are illustrated in Figure 4, with the Business-as-Usual case shown for comparison. Only the best-estimate of the temperature rise is shown in each case.

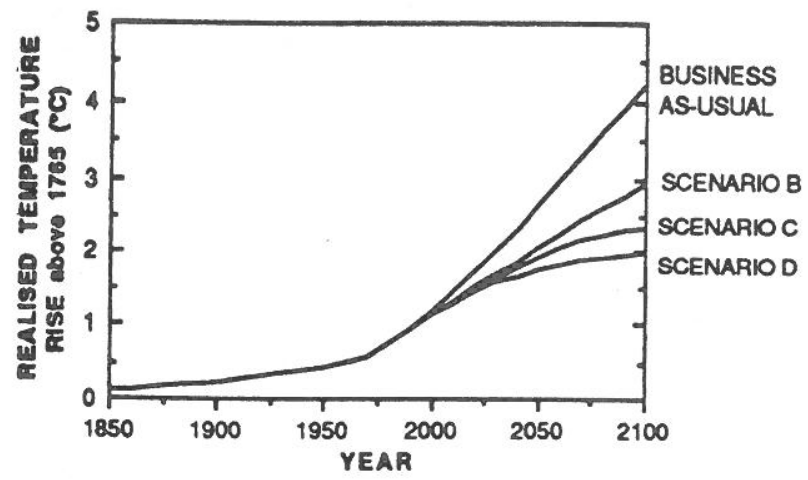

Figure 4 - Simulations of the increase in global mean temperature from 1850-1990 due to observed increases in greenhouse gases, and predictions of the rise between 1990 and 2100 resulting from the IPCC Scenario B, C and $D$ emissions, with the Business-as-Usual case for comparison.

The indicated range of uncertainty in global temperature rise given above reflects a subjective assessment of uncertainties in the calculation of climate response, but does not include those due to the transformation of emissions to concentrations, nor the effects of greenhouse gas feedbacks.

\section{What will be the pattems of climate change by 2030 ?}

Knowledge of the global mean warming and change in precipitation is of limited use in determining the impacts of climate change, for instance on agriculture. For this we need to know changes regionally and seasonally.

Models predict that surface air will warm faster over land than over oceans, and a minimum of warming will occur around Antarctica and in the northern North Atlantic region.

There are some continental-scale changes which are consistently predicted by the highest resolution models and for which we understand the physical reasons. The warming is predicted to be $50-100 \%$ greater than the global mean in high northern latitudes in winter, and substantially smaller than the global mean in regions of seaice in summer. Precipitation is predicted to increase on average in middle and high latitude continents in winter (by some $5-10 \%$ over $35-55^{\circ} \mathrm{N}$ ).

\section{How will climate extremes and extreme events change?}

Changes in the variability of weather and the frequency of extremes will generally have more impact than changes in the mean climate at a particular location. With the possible exception of an increase in the number of intense showers, there is no clear evidence that weather variability will change in the future. In the case of temperatures, assuming no change in variability, but with a modest increase in the mean, the number of days with temperatures above a given value at the high end of the distribution will increase substantially. On the same assumptions, there will be a decrease in days with temperatures at the low end of the distribution. So the number of very hot days or frosty nights can be substantially changed without any change in the variability of the weather. The number of days with a minimum threshold amount of soil moisture (for viability of a certain crop, for example) would be even more sensitive to changes in average precipitation and evaporation.

If the large-scale weather regimes, for instance depression tracks or anticyclones, shift their position, this would effect the variability and extremes of weather at a particular location, and could have a major effect. However, we do not know if, or in what way, this will happen.

\section{Will storms increase in a warmer world?}

Storms can have a major impact on society. Will their frequency, intensity or location increase in a warmer world?

Present models do not resolve smaller-scale disturbances, so it will not be possible to assess changes in storminess until results from higher resolution models become available in the next few years.

\section{Climate change in the longer term}

The foregoing calculations have focussed on the period up to the year 2100; it is clearly more difficult to make calculations for years beyond 2100 . However, while the timing of a predicted increase in global temperatures has substantial uncertainties, the prediction than an increase will eventually occur is more certain. Furthermore, some model calculations that have been extended beyond 100 years suggest that, with continued increases in greenhouse climate forcing, there could be significant changes in the ocean circulation, including a decrease in North Atlantic deep water formation.

\section{Other factors which could influence future climate}

Variations in the outpot of solar energy may also affect climate. However the variation in solar intensity changes sign so that over longer time-scales the increases in greenhouse gases are likely to be more important. Aerosols as a result of volcanic eruptions can lead to a cooling at the surface which may oppose the greenhouse warming for a few years following an eruption. Again, over longer periods the greenhouse warming is likely to dominate.

Human activity is leading to an increase in aerosols in the lower atmosphere, mainly from sulphur emissions. These have two effects, both of which are difficult to quantify but which may be significant particularly at the regional level. The first is the direct effect of the aerosols on the radiation scattered and absorbed by the atmosphere. The second is an indirect effect whereby the aerosols affect the microphysics of clouds leading to an increased cloud reflectivity. Both these effects might lead to a significant regional cooling; a decrease in emissions of sulphur might be expected to increase global temperatures. 


\section{CONFIDENCE IN PREDICTIONS FROM CLIMATE MODELS}

What confidence can we have that climate change due to increasing greenhouse gases will look anything like the model predictions? Weather forecasts can be compared with the actual weather the next day and their skill assessed; we cannot do that with climate predictions. However, there are several indicators that give us some confidence in the predictions from climate
models.

When the latest atmospheric models are run with the present atmospheric concentrations of greenhouse gases and observed boundary conditions their simulation of present climate is generally realistic on large scales, capturing the major features such as the wet tropical convergence zones and mid-latitude depression belts, as well as the contrasts between summer and winter circulations. The models also simulate the observed variability; for example, the large day-to-day pressure variations in the middle latitude depression belts and the maxima in interannual variability responsible for the very different character of one winter frem another both being represented. However, on regional scales $(2,000 \mathrm{~km}$ or less), there are significant errors in all models.

Overall confidence is increased by atmospheric models' generally satisfactory portrayal of aspects of variability of the atmosphere for instance those associated with variations in sea surface temperature. There has been some success in simulating the general circulation of the ocean, including the patterns (though not always the intensities) of the principal currents, and the distributions
of tracers added to the ocean.

Atmospheric models have been coupled with simple models of the ocean to predict the equilibrium response to greenhouse gases under the assumption that the model errors are the same in a changed climate. The ability of such models to simulate important aspects of the climate of the last ice age generates confidence in their usefulness. Atmospheric models have also been coupled with multi-layer ocean models (to give coupled ocean-atmosphere GCMs) which predict the gradual response to increasing atmosphere can be simula the ocean and the to small-scale errors which leads to a drift away from the coupling of ocean and atmosphere models reveals a sttong sensitivity to the exchange of heat between acean and from the observed climate. As yet, these errors must be removed by adjustments simple representations of the ocean and those using as do occur gives us some confidence in the results.

Because of long-period couplings between different components of the climate system, for example between ocean and atmosphere, the Earth's climate would still vary without being perturbed by any external influences. This natural variablity could act to add to, or substract from, any human-made warming; on a century time-scale this would be less than changes expected from greenhouse gas increases.

\section{How much confidence do we have in our predictions?}

Uncertainties in the above climate predictions arise from our imperfect knowledge of:

\section{future rates of human-made emissions}

how these will change the atmospheric concentrations of greenhouse gases

the response of climate to these changed concentrations

Firstly, it is obvious that the extent to which climate will change depends on the rate at which greenhouse gases (and other gases which affect their concentrations) are emitted. This in turn will be determined by various complex economic and sociological factors. Scenarios of future emissions were generated with IPCC WGIII and are described in the Annex to this Summary.

Secondly, because we do not fully understand the sources and sinks of the greenhouse gases, there are uncertainties in our calculations of future concentrations arising from a given emissions scenario. We have used a number of models to calculate concentrations and chosen a best estimate for each gas. In the case of carbon dioxide, for example, the concentration increase between 1990 and 2070 due to the Business-as-Usual emissions scenario spanned almsot a factor of two between the highest and lowest model result (corresponding to a range in radiative forcing change of about $50 \%$ ).

Furthermore, because natural sources and sinks of greenhouse gases are sensitive to a change in climate, they may substantially modify future concentrations (see earlier section: "Greenhouse gas feedbacks"). It appears that, as climate warms, these feedbacks will lead to an overall increase, rather than decrease, in natural greenhouse gas abundances. For this reason, climate change is likely to be greater than the estimates we have given.

Thirdly, climate models are only as good as our understanding of the processes which they describe, and this is far from perfect. The ranges in the climate predictions given above reflect the uncertainties due to model imperfections; the largest of these is cloud feedback (those factors affecting the cloud amount and distribution and the interaction of clouds with solar and terrestrial radiation), which leads to a factor of two uncertainty in the size of the warming. Others arise from the transfer of energy between the atmosphere and ocean, the atmosphere and land surfaces, and betweep the upper and deep layers of the ocean. The treatment of sea-ice and convection in the models is also crude. Nevertheless, for reasons given in the box above, we have substantial confidence that models can predict at least the broad-scale features of climate change. 
Furthermore, we must recognise that our imperfect understanding of climate processes (and corresponding ability to model them) could make us vulnerable to surprises; just as the human-made ozone hole over Antarctica was entirely unpredicted. In particular, the ocean circulation, changes in which are thought to have led to periods of comparatively rapid climate change at the end of the last ice age, is not well observed, understood or modelled.

\section{Will the climate of the future be very different?}

When considering future climate change, it is clearly essential to look at the record of climate variation in the past. From it we can learn about the range of natural climate variability, to see how it compares with what we expect in the future, and also look for evidence of recent climate change due to man's activities.

Climate varies naturally on all time-scales from hundreds of millions of years down to the year-to-year. Prominent in the Earth's history have been the 100,000 year glacialinterglacial cycles when climate was mostly cooler than at present. Global surface temperatures have typically varied by $5-7^{\circ} \mathrm{C}$ through these cycles, with large changes in ice volume and sea level, and temperature changes as great as $10-15^{\circ} \mathrm{C}$ in some middle and high latitude regions of the Northern Hemisphere. Since the end of the last ice age, about 10,000 years ago, global surface temperatures have probably fluctuated by little more than $1^{\circ} \mathrm{C}$. Some fluctutions have lasted several centuries, including the Little Ice Age which ended in the nineteenth century and which appears to have been global in extent.

The changes predicted to occur by about the middle of the next century due to increases in greenhouse gas concentrations from the Business-as-Usual emissions will make global mean temperatures higher than they have been in the last 150,000 years.

The rate of change of global temperatures predicted for Business-as-Usual emissions will be greater than those which have occurred naturally on Earth over the last 10,000 years, and the rise in sea level will be about three to six times faster than that seen over the last 100 years or so.

\section{Has man already begun to change the global climate?}

The instrumental record of surface temperature is fragmentary until the mid-nineteenth century, after which it slowly improves. Because of different methods of measurement, historical records have to be harmonised with modern observations, introducing some uncertainty. Despite these problems we believe that a real warming of the globe of $0.3^{\circ} \mathrm{C}-0.6^{\circ} \mathrm{C}$ has taken place over the last century; any bias due to urbanisation is likely to be less than $0.05^{\circ} \mathrm{C}$.

Moreover since 1900 similar temperature increases are seen in three independent data sets: one collected over land and two over the oceans. Figure 5 shows current estimates of smoothed global-mean surface temperature over land and ocean since 1860 . Confidence in the record has been increased by their similarly to recent satellite measurements of mid-tropospheric temperatures.

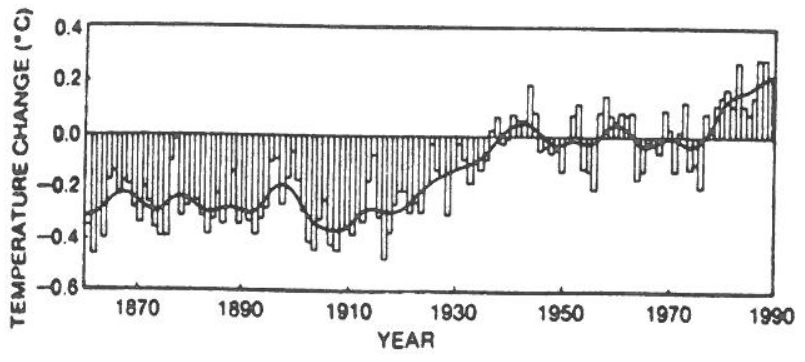

Figure 5 - Global-mean combined land-air and sea-surface temperature, 1861-1989, relative to the average for 1951-1980.

Although the overall temperature rise has been broadly similar in both hemispheres, it has not been steady, and differences in their rates of warming have sometimes persisted for decades. Much of the warming since 1900 has been concentrated in two periods, the first between about 1910 and 1940 and the other since 1975; the five warmest years on record have all ben in the 1980s. The Northern Hemisphere cooled between the 1940s and the early 1970s when Southern Hemisphere temperatures stayed nearly constant. The pattern of global warming sicne 1975 has been uneven with some regions, mainly in the northern hemisphere, continuing to cool until recently. This regional diversity indicates that future regional temperature changes are likely to differ considerably from a global average.

The conclusion that global temperature has been rising is strongly supported by the retreat of most mountain glaciers of the world since the end of the nineteenth century and the fact that global sea level has risen over the same period by an average of 1 to $2 \mathrm{~mm}$ per year. Estimates of thermal expansion of the oceans, and of increased melting of mountain glaciers and the ice margin in West Greenland over the last century, show that the major part of the sea level rise appears to be related to the observed global warming. This apparent connection between observed sea level rise and global warming provides grounds for believing that future warming will lead to an acceleration in sea level rise.

The size of the warming over the last century is broadly consistent with the predictions of climate models, but is also of the same magnitude as natural climate variability. If the sole cause of the observed warming were the human-made greenhouse effect, then the implied climate sensitivity would be near the lower end of the range inferred from the models. The observed increase could be largely due to natural variability; alternatively this variability and other man-made factors could have offset a still larger man-made greenhouse warming. The unequivocal detection of the enhanced greenhouse effect from observations is not likely for a decade or more, when the commitment to future climate change will then be considerably larger than it is today.

Global-mean temperature alone is an inadequate indicator of greenhouse-gas-induced climatic change. Identifying the causes of any global-mean temperature change requires examination of other aspects of the changing climate, particularly its spatial and temporal characteristics - the 
man-made climate change "signal". Patterns of climate change from models such as the Northern Hemisphere warming faster than the Southern Hemisphere, and surface air warming faster over land than over oceans, are not apparent in observations to date. However, we do not yet know what the detailed "signal" looks like because we have limited confidence in our predictions of climate change patterns. Furthermore, any changes to date could be masked by natural variability and other (possibly manmade) factors, and we do not have a clear picture of these.

\section{How much will sea level rise?}

Simple models were used to calculate the rise in sea level to the year 2100; the results are illustrated below. The calculations necessarily ignore any long-term changes, unrelated to greenhouse forcing, that may be occurring but cannot be detected from the present data on land ice and the ocean. The sea level rise expected from 1990-2100 under the IPCC Business-as-Usual emissions scenario is shown in Figure 6. An average rate of global mean sea level rise of about $6 \mathrm{~cm}$ per decade over the next century (with an uncertainty range of $3-10 \mathrm{~cm}$ per decade). The predicted rise is about $20 \mathrm{~cm}$ in global mean sea level by 2030 , and $65 \mathrm{~cm}$ by the end of the next century. There will be significant regional variations.

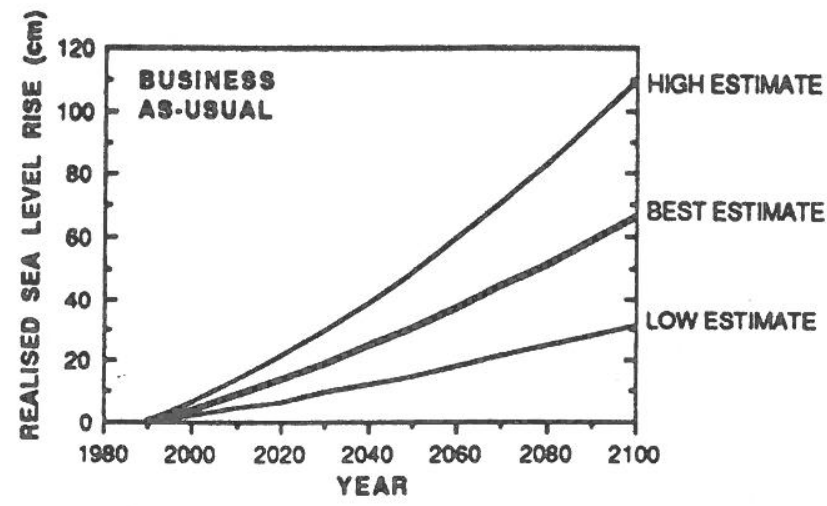

Figure 6 - Sea level rise predicted to result from Business-as-Usual emissions, showing the best-estimate and range.

The best estimate in each case is made up mainly of positive contributions from thermal expansion of the oceans and the melting of glaciers. Although, over the next 100 years, the effect of the Antarctic and Greenland ice sheets is expected to be small, they make a major contribution to the uncertainty in predictions.

Even if greenhouse forcing increased no further, there would still be a commitment to a continuing sea level rise for many decades and even centuries, due to delays in climate, ocean and ice mass responses. As an illustration, if the increases in greenhouse gas concentrations were to suddenly stop in 2030, sea level would go on rising from 2030 to 2100 , by as much again as from 1990-2030, as shown in Figure 7.

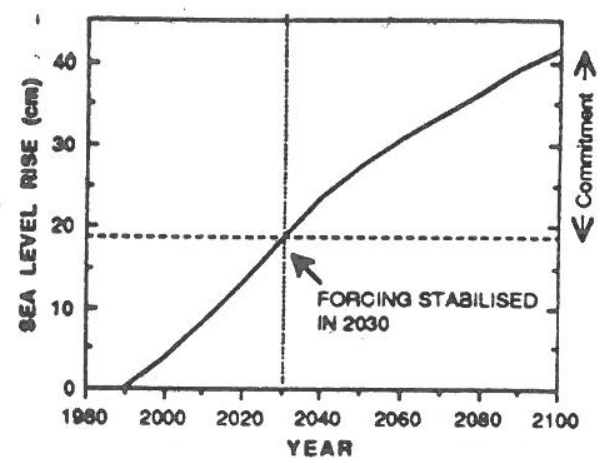

Figure 7 - Commitment to sea level rise in the year 2030. The curve showns the sea level rise due to Business-as-Usual emissions to 2030, with the additional rise that would occur in the remainder of the century even if climate forcing was stabilised in 2030.

Predicted sea level rise due to the other three emissions scenarios are shown in Figure 8, with the Business-asUsual case for comparison; only best-estimate calculations are shown.

The West Antarctic Ice Sheet is of special concern. A large portion of it, containing an amount of ice equivalent to about $5 \mathrm{~m}$ of global sea level, is grounded far below sea

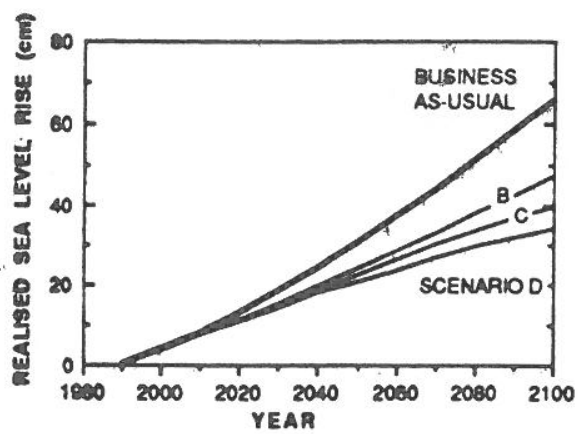

Figure 8-Model estimates of sea-level rise from 1990-2100 due to all four emissions scenarios.

level. There have been suggestions that a sudden outflow of ice might result from global warming and raise sea level quickly and substantially. Recent studies have shown that individual ice streams are changing rapidly on a decade-to-century time-scale; however this is not necessarily related to climate change. Within the next century, it is not likely that there will be a major outflow of ice from West Antarctica due directly to global warming.

Any rise in sea level is not expected to be uniform over the globe. Thermal expansion, changes in ocean circulation, and surface air pressure will vary from region to region as the world warms, but in an as yet unknown way. Such regional details await further development of more realistic coupled ocean-atmosphere models. In addition, vertical land movements can be as large or even larger than changes in global mean sea level; these movements have to be taken into account when predicting local change in sea level relative to land. 
The most severe effects of sea level rise are likely to result from extreme events (for example, storm surges) the incidence of which may be affected by climatic change.

\section{What will be the effect of climate change on ecosystems?}

Ecosystem processes such as photosynthesis and respiration are dependent on climatic factors and carbon dioxide concentration in the short term. In the longer term, climate and carbon dioxide are among the factors which control ecosystem structure, i.e., species composition, either directly by increasing mortality in poorly adapted species, or indirectly by mediating the competition between species. Ecosystems will respond to local changes in temperature (including its rate of change), precipitation, soil moisture and extreme events. Current models are unable to make reliable estimates of changes in these parameters on the required local scales.

Photosynthesis captures atmospheric carbon dioxide, water and solar energy and stores them in organic compounds which are then used for subsequent plant growth, the growth of animals or the growth of microbes in the soil. All of these organisms release carbon dioxide via respiration into the atmosphere. Most land plants have a system of photosynthesis which will respond positively to increased atmospheric carbon dioxide ("the carbon dioxide fertilization effect") but the response varies with species. The effect may decrease with time when restricted by other ecological limitations, for example, nutrient availability. It should be emphasized that the carbon content of the terrestrial biosphere will increase only if the forest ecosystems in a state of maturity will be able to store more carbon in a warmer climate and at higher concentrations of carbon dioxide. We do not yet know if this is the case.

The response to increased carbon dioxide results in greater efficiencies of water, light and nitrogen use. These increased efficiencies may be particularly important during drought and in arid/semi-arid and infertile areas.

Because species respond differently to climate change, some will increase in abundance and/or range while others will decrease. Ecosystems will therefore change in structure and composition. Some species may be displaced to higher latitudes and altitudes, and may be more prone to local, and possibly even global, extinction; other species may thrive.

As stated above, ecosystem structure and species distribution are particularly sensitive to the rate of change of climate. We can deduce something about how quickly global temperature has changed in the past from palaeoclimatological records. As an example, at the end of the last glaciation, within about a century, temperature increased by up to $5^{\circ} \mathrm{C}$ in the North Atlantic region, mainly in Western Europe. Although during the increase from the glacial to the current interglacial temperature simple tundra ecosystems responded positively, a similar rapid temperature increase applied to more developed ecosystems could result in their instability.
What should be done to reduce uncertainties, and how long will this take?

Although we can say that some climate change is unavoidable, much uncertainty exists in the prediction of global climate properties such as the temperature and rainfall. Even greater uncertainty exists in predictions of regional climate change, and the subsequent consequences for sea level and ecosystems. The key areas of scientific uncertainty are:

- clouds: primarily cloud formation, dissipation, and radiative properties, which influence the response of the atmosphere to greenhouse forcing;

oceans: the exchange of energy between the ocean and the atmosphere, between the upper layers of the ocean and the deep ocean, and transport within the ocean, all of which control the rate of global climate change and the patterns of regional change;

greenhouse gases: quantification of the uptake and release of the greenhouse gases, their chemical reactions in the atmosphere, and how these may be influenced by climate change;

polar ice sheets: which affect predictions of sea level rise.

Studies of land surface hydrology, and of impact on ecosystems, are also important.

To reduce the current scientific uncertainties in each of these areas will require internationally coordinated research, the goal of which is to improve our capability to observe, model and understand the global climate system.

Such a program of research will reduce the scientific uncertainties and assist in the formuatlion of sound national and international response strategies.

Systematic long-term observations of the system are of vital importance for understanding the natural variability of the Earth's climate system, detecting whether man's activities are changing it, parameterising key processes for models, and verifying model simulations. Increased accuracy and coverage in many observations are required. Associated with expanded observations is the need to develop appropriate comprehensive global information bases for the rapid and efficient dissemination and utilization of data. The main observational requirements are:

i) the maintenance and improvement of observations (such as those from satellites) provided by the World Weather Watch Programme of WMO.

ii) the maintenance and enhancement of a programme of monitoring, both from satellite-based and surfacebased instruments, of key climate elements for which accurate observations on a continuous basis are required, such as the distribution of important atmospheric constituents, clouds, the Earth's radiation budget, precipitation, winds, sea surface temperatures and terrestrial ecosystem extent, type and productivity. 


\section{DEFORESTATION AND REFORESTATION}

Man has been deforesting the Earth for millennia. Until the early part of the century, this was mainly in temperate regions, more recently it has been concentrated in the tropics. Deforestation has several potential impacts on climate: through the carbon and nitrogen cycles (where it can lead to changes in atmospheric carbon dioxide concentrations), through the change in reflectivity of terrain when forests are cleared, through its effect on the hydrological cycle (precipitation, evaporation and runoff) and surface roughness and thus atmospheric circulation which can produce remote effects on climate.

It is estimated that each year about $2 \mathrm{Gt}$ of carbon $(\mathrm{GtC})$ is released to the atmosphere due to tropical deforestation. The rate of forest clearing is difficult to estimate; probably until the mid-20th century, temperate deforestation and the loss of organic matter from soils was a more important contributor to atmospheric carbon dioxide than was the burning of fossil fuels. Since then, fossil fuels have become dominant; one estimate is that around $1980,1.6 \mathrm{GtC}$ was being released annually from the clearing of tropical forests, compared with about $5 \mathrm{GtC}$ from the burning of fossil fuels. if all the tropical forests were removed, the input is variously estimated at from 150 to $240 \mathrm{GtC}$; this would increase atmospheric carbon dioxide by 35 to 60 ppmv.

To analyse the effect of reforestation we assume that 10 million hectares of forests are planted each year for a period of 40 years, i.e., 4 million $\mathrm{km}^{2}$ would then have been planted by 2030 , at which time $1 \mathrm{GtC}$ would be absorbed annually until these forests reach maturity. This would happen in 40-100 years for most forests. The above scenario implies an accumulated uptake of about $20 \mathrm{GtC}$ by the year 2030 and up to $80 \mathrm{GtC}$ after 100 years. This accumulation of carbon in forests is equivalent to some $5-10 \%$ of the emission due to fossil fuel burning in the Business-as-Usual scenario.

Deforestation can also alter climate directly by increasing reflectivity and decreasing evapotranspiration. Experiments with climate models predict that replacing all the forests of the Amazon Basin by grassland would reduce the rainfall over the basin by about $20 \%$, and increase mean temperature by several degrees.

iii) the establishment of a global ocean observing system to measure changes in such variables as ocean surface topography, circulation, transport of heat and chemicals, and sea-ice extent and thickness.

iv) the development of major new systems to obtain data on the oceans, atmosphere and terrestrial ecosystems using both satellite-based instruments and instruments based on the surface, on automated instrumented vehicles in the ocean, on floating and deep sea buoys, and on aircraft and balloons.

v) the use of palaeo-climatological and historical instrumental records to document natural variability and changes in the climate system, and subsequent environmental response.

The modelling of climate change requires the development of global models which couple together atmosphere, land, ocean and ice models and which incorporate more realistic formulations of the relevant processes and the interactions between the different components. Processes in the biosphere (both on land and in the ocean) also need to be included. Higher spatial resolution than is currently generally used is required if regional patterns are to be predicted. These models will require the largest computers which are planned to be available during the next decades.

Understanding of the climate system will be developed from analyses of observations and of the results from model simulations. In addition, detailed studies of particular processes will be required through targetted observational campaigns. Examples of such field campaigns include combined observational and small-scale modelling studies for different regions, of the formation, dissipation, radiative, dynamical and microphysical properties of clouds, and ground-based (ocean and land) and aircraft measurements of the fluxes of greenhouse gases from specific ecosystems. In particular, emphasis must be placed on field experiments that will assist in the development and improvement of sub-grid-scale parametrizations for models.

The required program of research will require unprecedented international cooperation, with the World Climate Research Programme (WCRP) of the World Meteorological Organization and International Council of Scientific Unions (ICSU), and the International Geosphere-Biosphere Programme (IGBP) of ICSU both playing vital roles. These are large and complex endeavours that will require the involvement of all nations, particularly the developing countries. Implementation of existing and planned projects will require increased financial and human resources; the latter requirement has immediate implications at all levels of education, and the international community of scientists needs to be widened to include more members from developing countries.

The WCRP and IGBP have a number of ongoing or planned research programmes, that address each of the three key areas of scientific uncertainty. Examples include:

- clouds:

International Satellite Cloud Climatology Project (ISCCP)

Global Energy and Water Cycle Experiment (GEWEX).

oceans:

World Ocean Circulation Experiment (WOCE);

Tropical Oceans and Global Atmosphere (TOGA). 
trace gases:

Joint Global Ocean Flux Study (JGOFS);

International Global Atmospheric Chemistry (IGAC);

Past Global Changes (PAGES).

As research advances, increased understanding and improved observations will lead to progressively more reliable climate predictions. However considering the complex nature of the problem and the scale of the scientific programmes to be undertaken we know that rapid results cannot be expected. Indeed further scientific advances may expose unforeseen problems and areas of ignorance.
Time-scales for narrowing the uncertainties will be dictated by progress over the next $10-15$ years in two main areas:

- Use of the fastest possible computers, to take into account coupling of the atmosphere and the oceans in models, and to provide sufficient resolution for regional predictions.

- Development of improved representation of small-scale processes within climate models, as a result of the analysis of data from observational programmes to be conducted on a continuing basis well into the next century.

\section{ANNEX EMMISSIONS SCENARIOS FROM WORKING GROUP III OF THE INTERGOVERNMENTAL PANEL
ON CLIMATE CHANGE}

The Steering Group of the Response Strategies Working Group requested the USA and the Netherlands to develop emissions scenarios for evaluation by the IPCC Working Group I. The scenarios cover the emissions of carbon dioxide $\left(\mathrm{CO}_{2}\right.$, methane $\left(\mathrm{CH}_{4}\right)$, nitrious oxide $\left(\mathrm{N}_{2} \mathrm{O}\right)$ chlorofluorocarbons (CFCs), carbon monoxide (CO) and nitrogen oxides $\left(\mathrm{NO}_{x}\right)$ from the present up to the year 2100. Growth of the economy and population was taken common for all scenarios. Population was assumed to approach 10.5 billion in the second half of the next century. Economic growth was assumed to be $2-3 \%$ annually in the coming decade in the OECD countries and $3-5 \%$ in the Eastern European and developing countries. The economic growth levels were assumed to decrease thereafter. In order to reach the required targets, levels of technological development and environmental controls were varied.

In the Business-as-Usual scenario (Scenario A) the energy supply is coal intensive and on the demand side only modest efficiency increases are achieved. Carbon monoxide controls are modest, deforestation continues until the tropical forests are depleted and agricultural emissions of methane and nitrous oxide are uncontrolled. For CFCs the Montreal Protocol is implemented albeit with only partial participation. Note that the aggregation of national projections by IPCC Working Group III gives higher emissions $(10-20 \%)$ of carbon dioxide and methane by 2025 .

In Scenario B the energy supply mix shifts towards lower carbon fuels, notably natural gas. Large efficiency increases are achieved. Carbon monoxide controls are stringent, deforestation is reversed and the Montreal Protocol implemented with full participation.

In Scenario C a shift towards renewables and nuclear energy takes place in the second half of next century. CFCs are now phased out and agricultural emissions limited.

For Scenario D a shift to renewables and nuclear in the first half of the next century reduces the emissions of carbon dioxide, initially more or less stabilizing emissions in the industrialized countries. The scenario shows that stringent controls in industrialized countries combined with moderated growth of emissions in developing countries could stabilize atmospheric concentrations. Carbon dioxide emissions are reduced to $50 \%$ of 1985 levels by the middle of the next century.
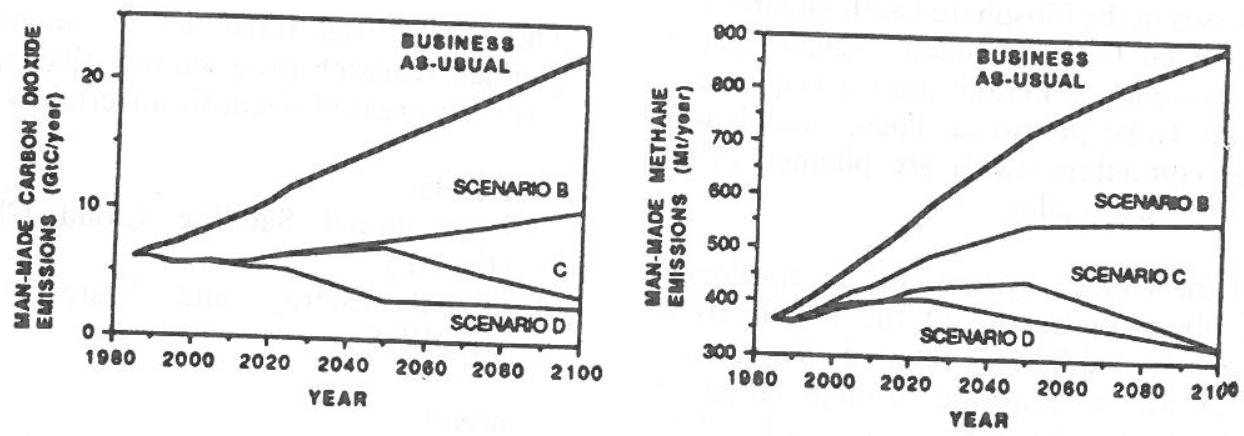

Man-made emissions of carbon dioxide and methane (as examples) to the year 2100, in the four scenarios developed by IPCC Working Group III 


\section{DE SUID-AFRIKAANSE KONFERENSIE OOR BINNENSHUISE OMGEWINGSKWALITEIT}

\section{Sake rakende Binnenshuise Omgewingskwaliteit - Hantering van Siekgebousindroom (SBS) Probleme}

\section{Eskom Kollege - Midrand Vrydag, 18 September 1992}

\section{1ste AANKONDIGING EN UITNODIGING VIR REFERATE}

\section{ORGANISEERDERS}

Die Konferensie word georganiseer deur die Binnenshuise Omgewingsgroep van die NASIONALE VERENIGING VIR SKOONLUG (NVSL) en die VERENIGING VAN EIENDOMSEIENAARS VAN SUID-AFRIKA (VEESA).

\section{DOELSTELLINGS}

- Om bewoners, administreerders, navorsers en verwante professies betrokke by binnenshuise omgewingskwaliteit te verenig ter bespreking van sake rakende binnenshuise omgewingskwaliteit;

- om samewerking in Suid-Afrika te stimuleer ten einde siekgebousindroom (SBS)-probleme op te los.

\section{ONDERWERPE}

- Allergieë en ander sensitiewe reaksies

- Residensiële binnenshuise lugbesoedeling

- Geboudienste en onderhoud

- Gebouprestasie en evaluering

- Fasiliteitsbestuur en SBS-konflikte

- Gebouventilasie, -filtrasie en -lugsuiwering

- Multidissiplinêre studies vir binnenshuise omgewingskwaliteit

- Binnenshuise klimaat en gemak $\left({ }^{*}\right.$ akoestiek ${ }^{*}$ beligting $*$ ruimte $*$ temperatuur)

- Die rol van argitektuur in gebou-ontwerp

- Mediese aspekte van SBS

- Omgewingsregulasies, beleid en riglyne vir gesondheid, gemak en produktiwiteit

- Nasionale en internasionale perspektiewe

\section{WIE BEHOORT BY TE WOON}

Omgewingsingenieurs

Fasiliteits- en boubestuurders

Gemeenskapsadministreerders/plaaslike besture
Omgewingsnavorsers en studente

Universiteite en technikons

Ventilasie-ingenieurs en technici

Nywerheids- en industriële bestuurders

Beroepshigiëniste

Ergonomiste

Medici

Gesondheidswerkers

Argitekte

\section{UITNODIGING VIR REFERATE}

Referate oor bogenoemde onderwerpe word uitgenooi:

Tradisionele referate (mondelings): ses bladsye vir insluiting in die gebinde verrigtinge van die konferensie.

- Plakkaatreferate: vir grafiese voordragte,'n ses-bladsy abstrak vir insluiting in die gebinde verrigtinge van die konferensie.

Voornemende outeurs van referate (mondelings en plakkate) moet die aangehegte antwoordblad invul en terugstuur tesame met 'n abstrak van nie meer as 300 woorde (een A4-bladsy) nie later nie as 1 Mei 1992. Outeurs sal teen 31 Mei 1992 weet of hulle referate aanvaar is. Alle referate sal taalkundig gekorrigeer word, maar nie gerefereer word nie. Finale referate ingestuur te word as 'n kamera-gereed-kopie gedruk op 'n hoë kwaliteit drukker, teen 30 Junie 1992, indien moontlik. Outeurs moet in ag neem dat referate teruggestuur kan word vir korreksies.

Die organiseerders behou die reg voor om 'n referaat wat vir mondelingse aanbieding ingestuur is, na die plakkaatsessie toe te ken, en omgekeerd.

\section{HOOFSPREKER}

Die hoofspreker sal dr John $\mathbf{R}$ Girman van die Indoor Air Division, US Environmental Protection Agency wees. Ander outoriteite op binnenshuise lugbesoedeling sal ook genooi word om die konferensiegangers toe te spreek.

\section{TAAL}

Die amptelike taal van die konferensie sal Engels wees.

\section{UITSTALLING}

'n Uitstalling van omgewingsmoniteer-, suiwerings-, filtreer- en lugversorgingstoerusting sal gehou word. Enige persoon wat belangstel om uit te stal by die konferensie, moet asseblief die relevante gedeelte van die antwoordblad voltooi en aanstuur waarna verdere besonderhede aan hulle gestuur sal word. Hierdie konferensie volg op die baie suksesvolle 1ste Suid-Afrikaanse Konferensie op dieselfde onderwerp wat deur ongeveer 300 besluitnemers in die veld van binnenshuise omgewingskwaliteit en verwante industrieë is. Die koste per uitstalruimte sal R1 250 wees. 
'n Skemerkelkonthaal waarna alle geregistreerde konferensiegangers uitgenooi word, sal op die aand van die konferensie plaasvind.

\section{AKKOMMODASIE}

Studente- en luukse akkommodasie is bespreek op die Eskom Kollege-kampus. Besonderhede oor die tariewe en fasiliteite sal tydens die volgende aankondiging gesirkuleer word. Eskom Kollege verskaf 'n diensbus om konferensiegangers vanaf Jan Smuts Lughawe te vervoer. 'n Nominale fooi sal hiervoor gehef word. Geen ander vervoer sal deur die organiseerders verskaf word nie.

\section{INSKRYWINGSFOOIE}

Die inskrywingsfooi is voorlopig gestel op R250 vir NVSLen VEESA-lede en R300 vir nie-lede. Outeurs wie se referate aanvaar word sal op 'n $40 \%$-afslag op fooie geregtig wees. Moet nie nou enige betaling stuur nie. Fooie is slegs betaalbaar na bevestiging in die finale aankondiging.
Terugsending van antwoordblad/voorlegging van abstrak ................. Mei

Finale kamera-gereed-kopie van referaat aan organiseerders $\ldots \ldots \ldots \ldots \ldots$ Augustus

Konferensie 18 September

\section{KORRESPONDENSIE EN NAVRAE}

Die finale aankondiging sal in Julie 1992 uitgereik word. Alle korrespondensie, navrae en abstrakte van referate moet gestuur word aan:

\section{CONFERENCE PLANNERS}

Aandag: Cilla Taylor \& Ammie Wissing Posbus 82

IRENE

Tel: (012) 63-1681

1675 